\title{
Correction to: Atypical hyperglycemia presentation suggests considering a diagnostic of other types of diabetes: first reported GCK-MODY in Perú
}

Juan Carlos Lizarzaburu-Robles ${ }^{1,2^{*}}$, Juan Carlos Gomez-de-la-Torre ${ }^{3}$, María del Carmen Castro-Mujica ${ }^{3}$, Flor Vento ${ }^{1}$, Sofia Villanes ${ }^{1}$, Elizabeth Salsavilca ${ }^{2}$ and Chris Guerin ${ }^{4}$

\section{Correction to: Clin Diab Endocrinol} https://doi.org/10.1186/s40842-019-0091-x

It was highlighted that the original article [1] contained an error regarding the nomenclature in the gene described. This was incorrectly captured as c.629 T > C, p.Met210Thr. The correct form is c.629C $>\mathrm{T}$ p.(Thr210Met). This error appeared in the Case Presentation section of the Abstract, in the Case Presentation section in the main body of the article and in the legend of Fig. 3. The original article has been updated.

\footnotetext{
Author details

${ }^{1}$ Hospital Central de la Fuerza Aérea del Perú, Lima, Peru. ${ }^{2}$ Asociación para la Prevención, Educación e Investigación en Diabetes - APREDIAB, Lima, Peru. ${ }^{3}$ Sequence Reference Lab, Lima, Peru. ${ }^{4}$ Advanced Metabolic Care and Research San Diego, San Diego, USA.
}

Published online: 17 February 2020

\section{Reference}

1. Lizarzaburu-Robles, et al. Atypical hyperglycemia presentation suggests considering a diagnostic of other types of diabetes: first reported GCKMODY in Perú. Clin Diab Endocrinol. 2020;6:3. https://doi.org/10.1186/ s40842-019-0091-X.

The original article can be found online at https://doi.org/10.1186/s40842 019-0091-x

* Correspondence: juancarlosliro@yahoo.com

${ }^{1}$ Hospital Central de la Fuerza Aérea del Perú, Lima, Peru

${ }^{2}$ Asociación para la Prevención, Educación e Investigación en Diabetes -

APREDIAB, Lima, Peru

Full list of author information is available at the end of the article

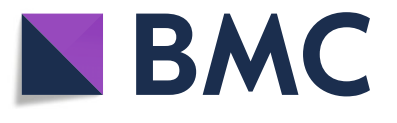

(c) The Author(s). 2020 Open Access This article is distributed under the terms of the Creative Commons Attribution 4.0 International License (http://creativecommons.org/licenses/by/4.0/), which permits unrestricted use, distribution, and reproduction in any medium, provided you give appropriate credit to the original author(s) and the source, provide a link to the Creative Commons license, and indicate if changes were made. The Creative Commons Public Domain Dedication waiver (http://creativecommons.org/publicdomain/zero/1.0/) applies to the data made available in this article, unless otherwise stated. 